\title{
連続焼鈍におけるロール冷却時の
}

\section{Study on Heat Buckling and Shape Problems during Roller Quenching in the Continuous Annealing Line}

Naotake Yoshinara, Shuzo FukUdA and Yasushi UENo

Synopsis :

In the operation of continuous annealing lines for thin strips, one of the main problems is to ensure a good flatness especially during roller quenching.

This paper deals with the heat buckling of strip during roller quenching and the pinch defect, namely, folding up of the buckled portion on the roller.

The theoretical analysis on those phenomena is carried out. It allows clarification of those mechanisms, factors and countermeasures.

The pinch index is presented, quantitatively showing the influence of various factors on pinch defects. This index gives the prediction for shape defects in actual operation, and is useful for its prevention and the design of the roller quenching system in the continuous annealing line.

Key words: heat treatment; heat buckling; thermal stress; steel; strip; annealing; roller quench; shape problem.

\section{1. 緒}

言

各種の急冷方式を用いた冷延鋼板製造の連続焼針設備 の中で，ロール冷却方式は省エネルギー，設備コンパク 卜化の点で優れ，かつ酸洗不要という多くの長所を有す る.ストリップは内部を水冷されたロールに接触して冷 却され, 冷却速度 ${ }^{1)}$ は $100 \sim 400^{\circ} \mathrm{C} / \mathrm{s}$ と大きく, かつロー ルへのストリップの接触長さを変えることにより冷却停 止温度の制御も容易に行われる。

実ラインの操業において板の平坦形状の維持は重要で あり，加熱炉や均熱炉で発生する板幅方向の座屈に関す 万研究 ${ }^{2)-4)}$ が今までに行われ，ロール形状の座屈への 影響が明らかにされている。これらはライン方向の温度 勾配を無視し得る条件下でのロール形状に起因する不均 一張力による座屈の研究である。これらの著者はヒート バックルと称し,高温下の板の座屈現象を扱つているが, 熱応力による座屈はほとんど検討していない．

一方，ロール冷却方式の連続焼鈍ラインの場合，特に ロール冷却帯において形状不良の発生頻度が高いという 難点がある. 形状不良の主たる原因はライン方向の板の
温度勾配から生ずる熱応力による座屈であると考えた。 本論文では, ロール形状に起因する不均一張力は考えず, 全くのフラットロールを前提とし，熱応力による座屈お よび座屈波形が成長して折りたたみ込まれて縦じわにな る形状不良 (以後, 絞りと呼ぶ) に関して検討を行つた. そして，絞り発生の危険度を表す指標を導入し，これを 用いて実ラインに扔いて形状不良を生ぜしめない設備上 および操業上の条件を整理，明確化した。

\section{2. 形状不良の発生メカニズム}

ストリップを急冷した時の熱変形を調べるため, 有限 要素法による熱座屈解析を行つた．Fig. 1 に示すよう にロール接触部の冷却速度の大きい条件では，たとえ板 幅方向温度分布が完全に均一であつてもライン方向に急 激な温度勾配が存在する場合，急冷開始点付近に大きな 座屈波形が生ずる.

その理由を次に述べる.

急冷带ではストリップのすべての部位でライン方向の 収縮と共に幅方向の収縮が起こる．幅中心では単にライ ン方向収縮によるライン方向変位だけしか生じないが,

昭和 62 年 1 月 26 日受付 (Received Jan. 26,1987 )

* 日本鋼管(株)中央研究所 (Advanced Technology Research Center, Nippon Kokan K. K., 1-1 Minamiwatarida-cho Kawasaki-ku Kawasaki 210)

*2 日本鋼管(株)中央研究所（現：日本鋼管(株)研究総務部）(Advanced Technology Research Center, Now Research Administration Dept., Nippon Kokan K. K.) 


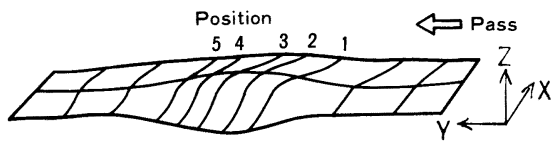

(i) View of buckled Shape $\left(1.0 \mathrm{~mm}^{\mathrm{t}}\right)$

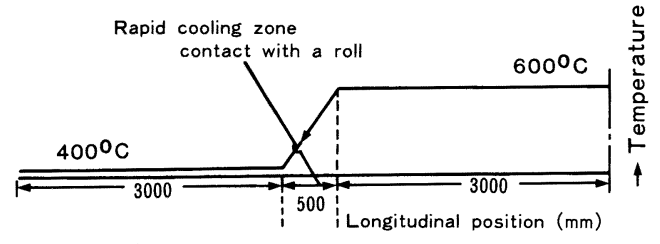

(ii) Temperature condition

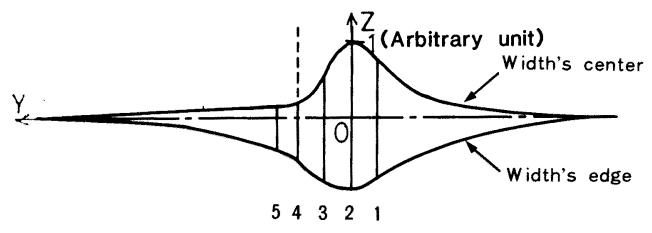

(iii) Longitudinal profile of buckling

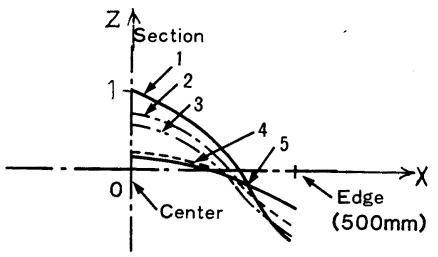

(iv) Section profile of buckling

Fig. 1. Calculation results on thermal buckling by finite element method.

一方幅端部ではライン方向変位のほかに幅中心方向に他 の部位にくらべて最も大きく変位する. 従つて, 急冷帯 における幅エッジ部の幅中心線に平行なライン方向長さ は相対的に最も短くなるので，いわば幅端部ほど短くな る細長い短冊を幅方向につないでストリップを構成した ような応力状態, すなわち急冷帯の幅中心付近に圧縮が 発生する状態となる．この圧縮により座屈が起こるので ある。

ロール冷却時に板形状が悪くなるのは, 板が急冷され ることにより必然的に発生する熱応力によつて座屈する からである．熱応力のうちで圧縮成分が大きくなると Fig. 1(i ) のような座屈波形が生じ，この座屈波形が 成長してさらに大きくなると水冷ロール通過時に折りた たみ込まれる現象, つまり絞りが発生し, 板の破断に達 することさえある．

\section{3. ロール冷却時に生ずる熱応力}

ストリップ急冷時に生ずる熱応力による座屈の原因で ある圧縮応力の要因を調べるため, 有限要素法による平

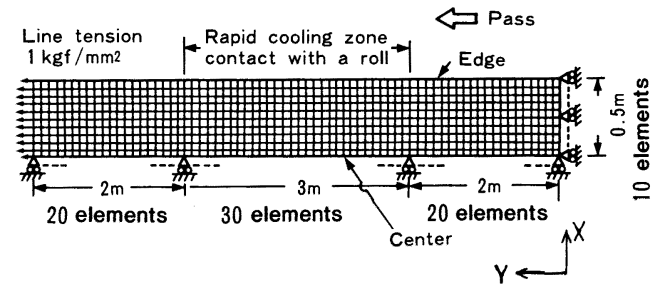

Fig. 2. Mesh and mechanical conditions.

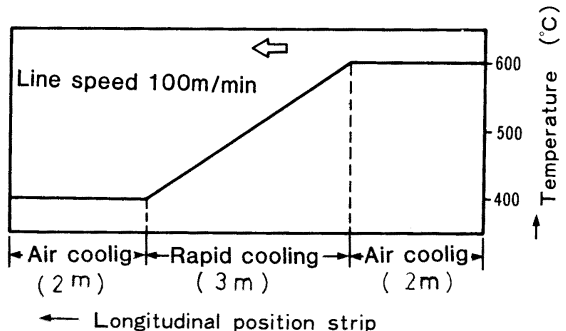

Fig. 3. Condition of temperature distribution.

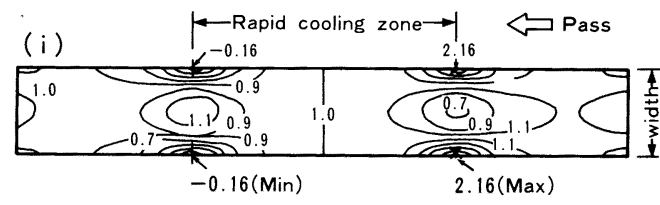

(ii) $\leftrightarrow$ Pass

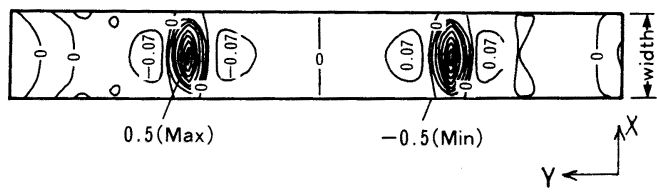

(i) Contours of longitudinal stress with an interval of $0.2 \mathrm{kgf} / \mathrm{mm}^{2}$ (ii) Contours of transverse stress with an interval of 0.07 $\mathrm{kgf} / \mathrm{mm}^{2}$

Fig. 4. Stress distribution of strip during roller quenching.

面熱弾性応力解析を行つた. 材料のヤング率とポアソン 比はそれぞれ $21000 \mathrm{kgf} / \mathrm{mm}^{2}, 0.3$ とし, 温度依存性は 考慮しなかつた。

\section{$3 \cdot 1$ 熱応力による座屆の危険部位}

Fig. 2 は有限要素法解析に用いる要素分割, 拘束条 件, 外力条件を示す. 板のライン方向には平均張力 1 $\mathrm{kgf} / \mathrm{mm}^{2}$ が加えられている. 対称条件により板幅の半 分を計算対象として, 初期温度 $600^{\circ} \mathrm{C}$ から Fig. 3 に示 す温度分布まで冷却される場合の熱応力を計算した。

Fig. 4 は面内応力分布の計算結果を示す. ライン方 向応力は急冷帯の開始と終了部を除くと外力による平均 張力 $1 \mathrm{kgf} / \mathrm{mm}^{2}$ に等しく，急冷開始部の板幅中心では 平均張力（ライン張力）より低下し, 急冷開始部の板幅 
端部では平均張力より増加している，また，急冷終了部 の板幅中心では平均張力より増加し，急冷終了部の板幅 端部では平均張力より低下する，すなわち，熱応力は急 冷帯の始まりと終わりの部分にのみ発生し，その值は互 いに逆符号になる.

板幅方向応力は急冷開始部と終了部のみに発生し，急 冷開始部で板幅中心に行くほど大きな圧縮応力が生じ， 急冷終了部では逆に板幅中心に行くほど大きな引張応力 が生ずる.

Fig. 4 はストリップ急冷時の熱応力状態を示してい るが，ライン張力が零の場合を模式的に示すと Fig. 5 のようになる. 座屈危険部は圧縮応力 (マイナスの応力) の発生している所である.ロール冷却 $(R Q)$ 開始部お よび終了部に圧縮応力が存在する，RQ 終了部では圧縮 応力が小さな領域に発生しているが，それにくらべると $\mathrm{RQ}$ 開始の幅中央部では圧縮応力が大きな領域に発生し

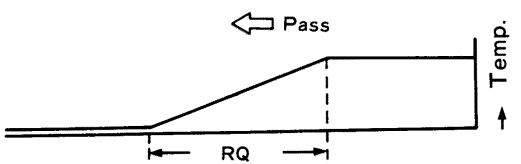

(i) Temperature change in the longitudial direction With no external tenston

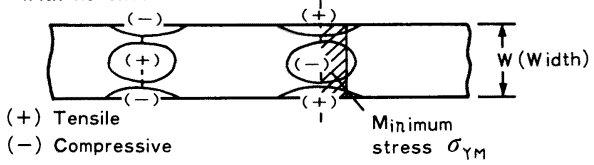

(ii) Longitudinal stress
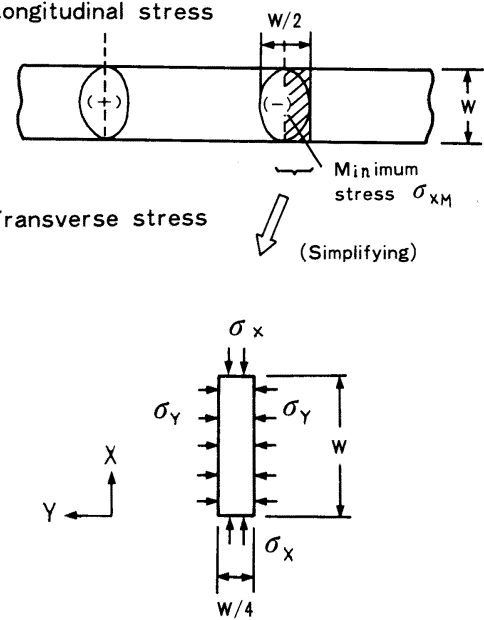

(iV) Simplified stress state at the start of Roller Quench(RQ)

Fig. 5. Simplified biaxial stress state of the dangerous part of buckling.
ており，しかも直交する 2 方向（ $X, Y$ 方向）から圧縮 を受けている状態なので，この部位の座屈の発生する危 険度は最も高いと考えられる．Fig. 1 に示した座屈波 形の山の頂点の位置にちようど対応している。

また，絞りとは縦じわ形状を示すことから，幅方向の 圧縮による座屈が最も大きな原因と考え，Fig. 5(iii) の圧縮応力の部位に注目する。この部位の左半分は水冷 ロールに巻きついていて，およそ $0.5 \mathrm{~m}$ の曲率半径を 有するので平坦な状態にくらべて臨界座屈応力ははるか に大きくなる5). 一方，斜線で示す右半分の部位は水冷 ロールに巻きついておらず，平坦であるので座屈しやす い. 従つて, この斜線部位の臨界座屈応力を以下で検討 する. 実際には，この部位の熱応力はある分布を有して いるが，一様な 2 軸応力場に近似して議論することにす る. $\mathrm{RQ}$ 開始部における幅方向およびライン方向の最小 応力をそれぞれ $\sigma_{X M}, \sigma_{Y M}$ とする. 一様応力は幅方向お よびライン方向にそれぞれ $\sigma_{X}, \sigma_{Y}$ と呼ぶことにする. この一様応力 $\sigma_{X}, \sigma_{Y}$ と $\sigma_{X M}, \sigma_{Y M}$ の関係を次に求める. Fig. 5( ii ) の斜線部では幅端部の小さな領域の引張 $(+)$ 応力を無視すると, 圧縮 $(-)$ 応力はほぼライン力 向に一定で幅中心から端に行くほど零に近づくと見なせ るので平均として $\sigma_{Y}=\frac{1}{2} \sigma_{Y M}$ が得られる. 一方, Fig. 5(iii）の斜線部では圧縮応力の絶対值は RQ 開始点の幅 中心が最も大きく，ライン方向および幅方向のいずれに 行くに従つて零になるので平均として $\sigma_{X}=\frac{1}{4} \sigma_{X M}$ とな る。

\section{$3 \cdot 2$ 座届を支眍する熱応力の要因}

(1)熱応力は板のライン方向温度勾配が大きいほど大

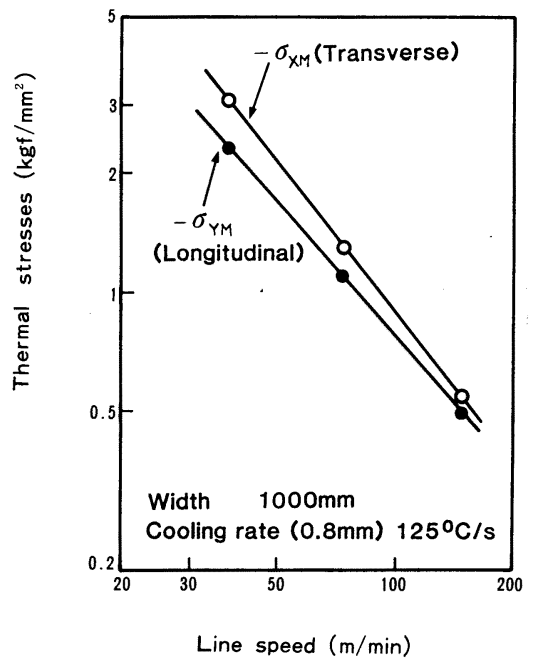

Fig. 6. Relationship between line speed and thermal compressive stress. 


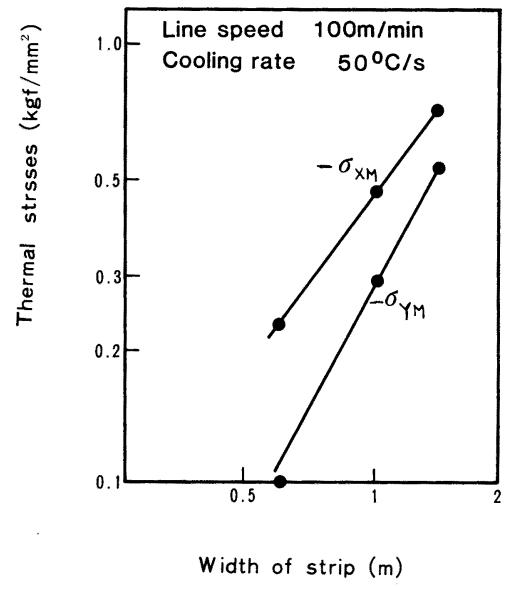

Fig. 7. Relationship between strip width and thermal compressive stress.

きくなるので, 冷却速度が大きいほど, また, ライン速 度が小さいほど熱応力は増加する. つまり, 冷却速度を 大きくすることとライン速度を小さくすることは熱応力 に対して同様の効果を与える.

Fig. 6 はライン速度と熱応力 $\sigma_{X M}, \sigma_{Y M}$ との関係を両 対数で示す. 熱応力はライン速度にほぼ反比例する.

( 2 )Fig. 7 はストリップ幅と熱応力 $\sigma_{X M}, \sigma_{Y M}$ との関 係を両対数で示す. 熱応力はストリップ幅にほぼ比例し て増加する。

\section{4. ストリップの座届特性}

ストリップ急冷時の座屈危険部の熱応力状態を Fig. 5 のように一様な 2 軸応力場に近似し,この 2 軸応力場 における板の座屈特性を調べることにする．

\section{$4 \cdot 12$ 軸応力場の座屆特性 ${ }^{5)}$}

2 軸応力場の臨界座屈応力と発生する応力の比を計算 し, この值により 2 軸応力場の座屈発生危険度を定量的 に表現する.この值を座屈指標 $B I$ (Buckling Index) と 呼ぶことにする. Fig. 8 に BI を求める計算手順を示す.

1）まず， 3 節で述べたように Fig. 5 に示す熱応力 $\sigma_{X M}, \sigma_{Y M}$ を有限要素法による計算から求める.

熱応力の要因としてロール冷却帯のストリップのライ ン方向温度勾配 $S\left({ }^{\circ} \mathrm{C} / \mathrm{m}\right)$ およびストリップ幅 $W$ が考 えられる. $S$ と $W$ が独立に影響を及ぼすものと見なす と 3.2 節の Fig. 6 と Fig. 7 に示した関係より, 熱応 力は次式で表すことができる.

$$
\begin{aligned}
& \sigma_{X M}=C_{1} \cdot S^{1.3} \cdot W^{1.4} \\
& \sigma_{Y M}=C_{2} \cdot S^{1.1} \cdot W^{1.8}
\end{aligned}
$$

ここで温度勾配 $S$ は次式で示される.

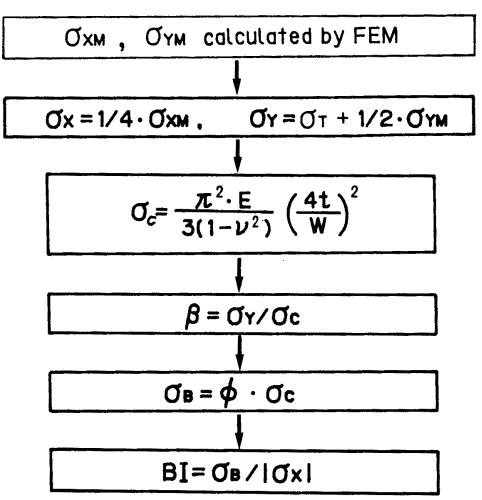

Fig. 8. Caliculation flow of buckling index.

$$
S=K_{1} \cdot\left(\frac{\alpha}{t \cdot V}\right)
$$

ここで $K_{1}:$ 定数

$\alpha:$ ロール冷却の総括熱貫流率 $\left(\mathrm{kcal} / \mathrm{m}^{2} \cdot \mathrm{h} \cdot{ }^{\circ} \mathrm{C}\right)$

$V:$ 通板速度 $(\mathrm{m} / \mathrm{min})$

$C_{1}, C_{2}$ は定数である.

(1) 式の変数 $S$ と $W$ の範囲はそれぞれ 50 $200^{\circ} \mathrm{C} / \mathrm{m}$ および 0.6 1.4 $\mathrm{m}$ であり,この条件下で( 1 ) 式が有効である. しかし， $S$ と $W$ の範囲をさらに拡張 して( 1 )式を今後用いることにする.

2 ) 座屈発生危険部位の応力状態を一様な 2 軸応力場 に近似する．その 2 軸応力を $\sigma_{X}$ と $\sigma_{Y}$ とする.

3 ) 熱応力以外に外部からライン張力 $\sigma_{T}$ が加わつて いるので, 合計したライン方向応力を $\left(\sigma_{Y}+\sigma_{T}\right)$ と置き 換える.

4 ) 単軸圧縮による臨界座屈応力 $\sigma_{C}$ を求める.

板厚 $t$ の長方形板の周辺が単純支持され，辺の長さ $W / 4$ に一様な圧縮を一方向に受ける時の臨界座屈応力 は

$$
\sigma_{c}=\frac{\pi^{2} \cdot E}{3\left(1-\nu^{2}\right)} \cdot\left(\frac{4 t}{W}\right)^{2}
$$

ここで $E:$ ヤグ率， $\nu:$ ポアソン比である.

5 ) $\sigma_{Y}$ と $\sigma_{C}$ の比を $\beta$ とおく.

6) 2 軸応力場を代表するものとして板幅方向応力を 用いると, この 2 軸応力場の臨界座屈応力 $\sigma_{B}$ を $\beta$ の関 数 $\phi$ と $\sigma_{C}$ の積で表す. $\phi$ は次のようにして求める.

一様な 2 軸面内応力 $\bar{\sigma}_{X}, \bar{\sigma}_{Y}$ が $X, Y$ 方向に作用する 厚さ $t$ の長方形板の面に垂直な方向のたわみの方程式 を, 周辺単純支持の条件で解くと次式が得られる.

$$
\begin{gathered}
\bar{\sigma}_{X}\left(\frac{m \pi}{a}\right)^{2}+\bar{\sigma}_{Y}\left(\frac{n \pi}{b}\right)^{2}=\frac{D}{t}\left[\left(\frac{m \pi}{a}\right)^{2}\right. \\
\left.+\left(\frac{n \pi}{b}\right)^{2}\right]^{2} \ldots \ldots \ldots \ldots \ldots \ldots \ldots \ldots \ldots \ldots \ldots \ldots \ldots \ldots \ldots \ldots \ldots \ldots \ldots \ldots \ldots \ldots
\end{gathered}
$$


ここで $D=E /\left(1-\nu^{2}\right) \cdot t^{3} / 12$

$a, b$ は長方形の $x, y$ 方向の辺の長さ.

$m, n$ は整数であり, 座屈モードの次数.

$b / a=4$ であるので( 3 )式は次のように書き直せる.

$\frac{\left|\bar{\sigma}_{x}\right|}{\sigma_{c}}=\frac{D \pi^{2}}{t}\left[1+\left(\frac{n}{4 m}\right)^{2}\right]^{2}-\left(\frac{n}{4 m}\right)^{2} \cdot \beta \cdots(4)$

$\phi$ はすべての整数 $m, n$ に対する $(4)$ 式の值の中で最

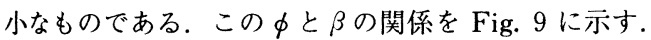

7 ) $\sigma_{B}$ と発生する熱応力 $\sigma_{X}($ 絶対値 $)$ との比を計算 すると $B I$ が次のように求まる.

$$
B I=\frac{\sigma_{B}}{\left|\sigma_{X}\right|}=K_{B} \cdot \phi \cdot \frac{E}{\left(1-\nu^{2}\right)}\left(\frac{V}{\alpha}\right)^{1.3} \cdot \frac{t^{3.3}}{W^{3.4}} \cdots \cdots \cdots
$$

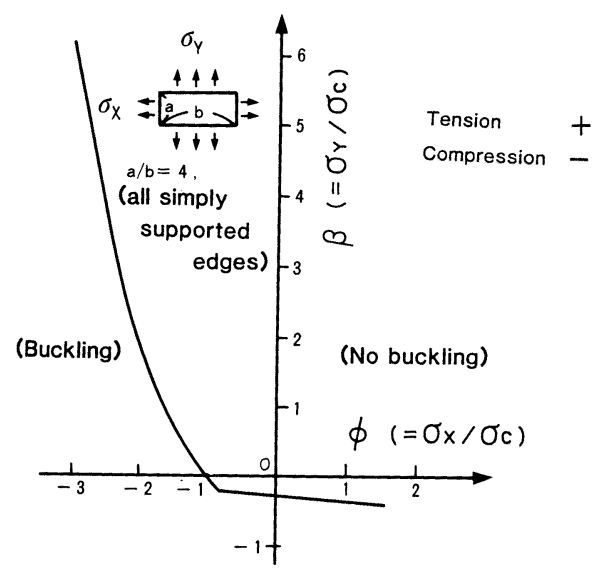

Fig. 9. Critical buckling stress state of a rectangular region in a strip under simplified biaxial stress state.
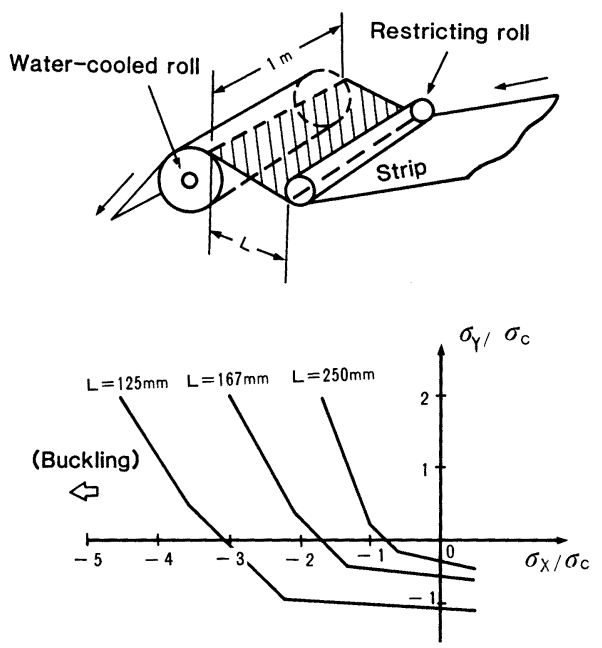

Fig. 10. Effect of the restricting roller on critical buckling stress.

$$
\text { ここで } K_{B}=0.19
$$

\section{$4 \cdot 2$ 座屆防止の押さえロール効果}

Fig. 10 に示すように押さえロールを水冷ロールのス トリップ入側に配置すると, 押さえロールと水冷ロール の間で面外変位できる部分が斜線部に制限される。この 長方形の寸法比 $W / L$ が大きくなるほど臨界座屈応力は 大きくなる. 座屈の発生する危険部は水冷ロールの手前 $W / 4$ の範囲に存在するので $L$ を $W / 4$ より小さくする と押さえロールと水冷ロールの間の部分では臨界座屈応 力が大きくなるが, 水冷ロールと反対側（入側）の座屈 危険部の領域が大きくなり, 臨界座屈応力が小さくなつ てくる.そして押さえロールを水冷ロールして $L<W / 8$ に近づけると押さえロールの手前の方が座屈しやすくな る. 従つて押さえロールの位置としては $L \cong W / 8$ が最 適值と思われる.

\section{5. 较り指 標}

\section{$5 \cdot 1$ 絞り指標の導出}

ストリップのロール冷却時の形状は操業条件によつて Table 1 のように変化すると考える，すなわち，平面応 力解析から求まる座屈発生の危険部位の圧縮応力 $\sigma_{X}$ が 臨界座屈応力 $\sigma_{B}$ になると座屈し, 軽度のふくらみ状を 呈する.そして，さらにこの部位の圧縮応力 $\sigma_{X}$ が $\sigma_{B}$ を超えて絞り発生限界応力 (以後この限界応力を $\sigma_{P}$ と する）に達すると「絞り」が生ずると考える， $\sigma_{P}$ を定 量的に求めるため次の仮定を置く.

(1) 座屈波形は板幅方向に正弦波であり，ライン方向 には変化していない.

( 2 )板面外への変形がないとして計算した面内圧縮応 力 $\sigma_{X}$ が $\sigma_{B}$ より大きければ実際には座屈してしまうの

Table 1. Changes of strip shape during roller quenching in the continuous annealing line.

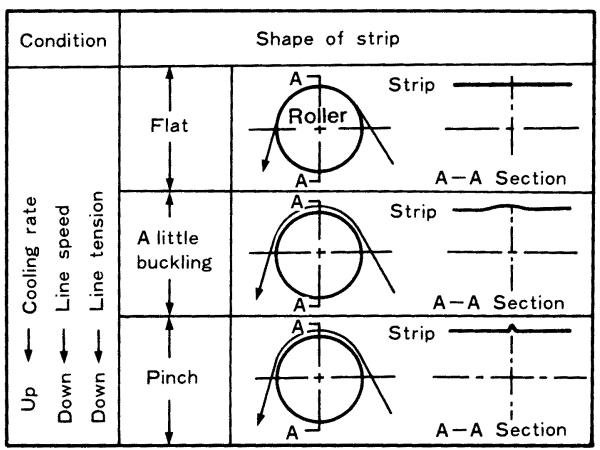


で， $\sigma_{B}$ の面内圧縮応力までしか維持できない. 従つて, $\sigma_{B}$ の大きさの面内压縮応力を維持したまま

$$
\left\{\sigma_{X}-\sigma_{B}\right\} / E
$$

に相当する伸び歪み余剰長さ分だけ面外へ変位する.

以上の仮定により

$$
\sigma_{A}=\sigma_{x}-\sigma_{B}
$$

とおくと, 正弦波の急峻度と伸び歪みの関係から

$$
\sigma_{A} / E=\left(\frac{\pi}{2} \cdot \frac{h}{W / 2}\right)^{2}
$$

ここで $h$ は波の高さ。

が成り立つ。

Fig. 11 に示す座屈波形がその形状を保つたまま水冷 ロールを通過できないほど成長した時，Fig. 12 のよう な「絞り」形状になると仮定する．この絞り発生条件は， ストリップの水冷ロール通過時の座屈した凸部の曲げ曲 げ戻しの弾性歪みエネルギー $J_{1}$ が絞り形状の完全塑性 曲げエネルギー $J_{2}$ より大きくなると絞るということで ある. $J_{1}$ および $J_{2}$ は次のようにして求めることができ る. 絞り発生前の座屈波を Fig. 11 に示す断面形状を持 つ梁と見なして，水冷ロール接触部 $\theta_{C}$ にて曲げ半径 $R$ に曲げ曲げ戻しを受けると考えると

$$
J_{1}=2 \cdot \frac{E \cdot I}{R} \cdot \theta_{c}
$$

となる.ここで $I$ は Fig. 11 に示す高さ $h$ の正弦波の 断面 2 次モーメントである.
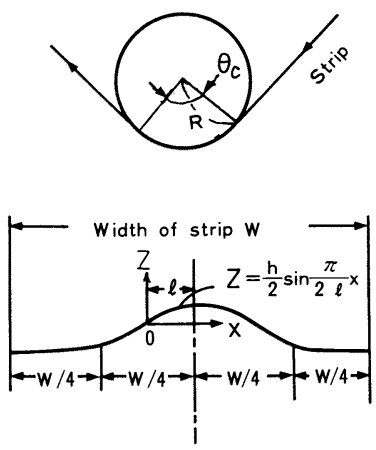

Fig. 11. Shape of buckling.

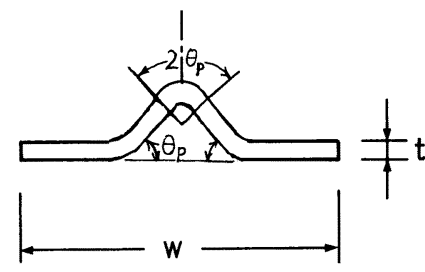

Fig. 12. Shape of pinched strip.

$$
\begin{aligned}
I & =4 \int_{0}^{l} t\left(\frac{h}{2}\right)^{2} \sin ^{2}\left(\frac{\pi}{2 l x}\right) \cdot d x \quad(l=W / 8) \\
& =\frac{t \cdot W}{16} h^{2}
\end{aligned}
$$

より

$$
J_{1}=\frac{t W E}{8 R} \cdot h^{2} \cdot \theta_{C}
$$

絞り発生時には水冷ロール接触部のストリップが Fig. 11 から Fig. 12 のような横断面形状に塑性曲げを 受け,ライン方向に正弦波的に Fig. 12 の $\theta_{P}$ が $0 \sim \pi / 4$ に周期的に変化すると考えると, SIEBEL の方法により6)

$$
\begin{aligned}
J_{2} & =4 \cdot\left(\frac{1}{4} t^{2} \cdot \sigma_{e}\right) \frac{\pi}{4}\left(\frac{\int_{0}^{\pi / 2} \sin \theta \cdot d \theta}{\pi / 2}\right) \\
& =\frac{1}{2} t^{2} \cdot \sigma_{e} \cdot \theta_{c}
\end{aligned}
$$

ここで $\sigma_{e}:$ ストリップの降伏応力.

従つて, 絞りの条件 $J_{1}=J_{2} に(9)$ 式と(10)式を代入す ると,

$$
h^{2}=\frac{4 \cdot \sigma_{e}}{E} \cdot \frac{t \cdot R}{W}
$$

が得られる.

(11)式を( 7 )式に代入することにより，絞り発生時の 応力 $\sigma_{A}=\sigma_{A}{ }^{*}$ とすれば, $\sigma_{A}^{*}$ は次のようになる.

$$
\sigma_{A}^{*}=4 \pi^{2} \sigma_{e} t R^{2} / W^{3}
$$

ストリップに発生する応力 $\sigma_{X}$ が $\left(\sigma_{A}{ }^{*}+\sigma_{B}\right)$ よりも大 きくなると絞りが発生すると考えられる.

次に, 絞り発生応力 $\sigma_{P}$ および絞り指標 (Pinch Index $=P I)$ を次のように定義する.

$$
\begin{aligned}
& \sigma_{P}=\sigma_{A}{ }^{*}+\sigma_{B} \\
& P I=\frac{\sigma_{P}}{\left|\sigma_{X}\right|} .
\end{aligned}
$$

$P I$ は絞り発生の危険度を表し，1より小さくなると極 めて絞り発生の危険が高くなることを意味する.（14)式 に(13)式を代入し，さらに(12)式および( 1 )式を用いて 整理すると,

$$
P I=\left(\frac{V}{\alpha}\right)^{1.3}\left\{K_{A} \cdot \sigma_{e} \cdot R^{2} \frac{t^{2.3}}{W^{4.4}}+K_{B} \cdot \phi \cdot \frac{E}{\left(1-\nu^{2}\right)} \frac{t^{3.3}}{W^{3.4}}\right\}
$$

$$
\text { ここで } K_{A}=0.90 \quad K_{B}=0.19
$$

\section{$5 \cdot 2$ 絞りの要因}

（15)式に基づいて絞りの要因の影響を検討する．ライ ン速度が大きく，ロール冷却の総括熱貫流率が小さく, ライン張力が大きいほど絞りにくい．また，ストリップ 寸法として板幅が小さく,板厚が大きいほど絞りにくい. 一方, 水冷ロールの半径とストリップの降伏応力は $B I$ 
Table 2. Equivalent change of factors on the pinch index (From the standard condition).

\begin{tabular}{lr|c}
\hline \multicolumn{1}{c|}{ Factor } & Equivalence \\
\hline Thickness & $t(\mathrm{~mm})$ & 0.1 \\
Width & $W(\mathrm{~m})$ & -0.1 \\
Overall coefficient of heat transfer & $\alpha\left(\mathrm{kcal} / \mathrm{m}^{2} \cdot \mathrm{h} \cdot{ }^{\circ} \mathrm{C}\right)$ & -300 \\
Line speed & $V(\mathrm{~m} / \mathrm{min})$ & 20 \\
Line tension & $\sigma_{T}\left(\mathrm{kgf} / \mathrm{mm}^{2}\right)$ & 0.8 \\
Roll diameter & $R(\mathrm{~m})$ & 0.4 \\
Yield stress & $\sigma_{e}\left(\mathrm{kgf} / \mathrm{mm}^{2}\right)$ & 30 \\
\hline
\end{tabular}

The standard condition : $t=0.8 \mathrm{~mm}, W=1 \mathrm{~m}$ $\alpha=1400 \mathrm{kcal} / \mathrm{m}^{2} \cdot \mathrm{h} \cdot{ }^{\circ} \mathrm{C}, V=105 \mathrm{~m} / \mathrm{min}, \sigma_{T}=1 \mathrm{kgf} / \mathrm{mm}^{2}$, $R=0.4 \mathrm{~m}, \sigma_{e}=10 \mathrm{kgf} / \mathrm{mm}^{2}$

には影響を及ぼさないが，PIへの影響があり，これら が大きいほど PI は大きくなつて絞りにくい. 種々の絞 り要因の影響度を Table 2 に示す。この表では表の下 部に示す基準条件付近では例えば板厚を $0.1 \mathrm{~mm}$ 増加す ることは板幅を $0.1 \mathrm{~m}$ 減少させるのと絞り発生の危険 度の観点では等しいことを示している.

\section{6. 実ラインの絞り対策への応用}

Fig. 13 中に示す二つの代表的な実ライン $A$ および $B$ の絞りに関する設備, 操業デー夕を用いて(15)式から求 まるPI と実機での絞り有無との比較を行う（15)式の 係数 $K_{A}, K_{B}$ を以前に示した值より小さく，それぞれ $0.15,0.032$ とすれば(15)式の $P I=1$ を満たす板厚と板 幅の関係の線（計算上の絞り発生限界線）は二つの実 イン $A, B$ の絞り発生限界を良く表現している. 以後, (15)式の $K_{A}, K_{B}$ はこれらの值を使用する. 係数 $K_{A}$, $K_{B} \cdot$ の值は 4,5 章で解析的に導いたものよりも実際には 小さくなつており，仮定した解析モデルよりもつと座屈 部分の周辺の拘束が緩やかであり, 絞り形状の塑性曲げ 歪みエネルギーがより小さくなつていると考えられる.

実ラインの操業では板厚が小さいほど，また板幅が大 きいほど絞り発生頻度が高いという経験がある。このこ とから, ある設備, 操業条件に対して(15)式の $P I=1$ から求まる絞り発生限界内にストリップ寸法を制限する 必要がある.

(15)式から，ライン速度が大きいほど PI は大きくな るので, 実ラインにおいて通板速度を上げて操業を行つ たところ, 非常に大きな絞り防止効果が得られた. 以後, 加熱炉の能力いつぱいに通板速度を上げて操業を行つて いる.

また, 実ラインのライン張力は通常 $1 \mathrm{kgf} / \mathrm{mm}^{2}$ であ つたが，ロール冷却帯の前後に張力付加装置を増設して $2.5 \sim 3 \mathrm{kgf} / \mathrm{mm}^{2}$ にライン張力を高めることにより大き な絞り防止効果を得ている. もち万ん, 水冷ロールはフ ラット形状である.

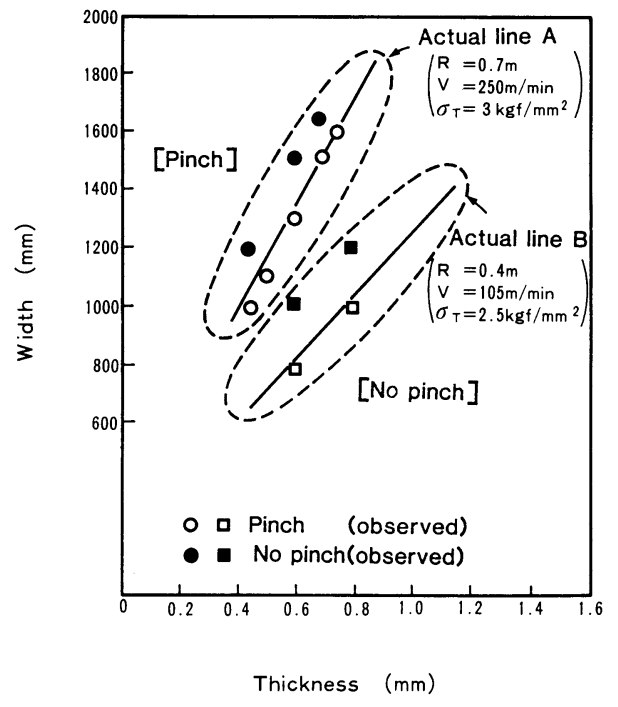

Fig. 13. Condition of strip size for pinch in roller quenching.

実ラインにおいて水冷ロールとして銅ロールを使用し た経験がある．銅ロールでは絞りが多発したが，銅ロー ルにくらべ 0.5 0.7 倍の総括熱貫流率を有する ${ }^{1)}$ 鉄 ロールに変えたところ, 絞り発生頻度が大きく隇少した.

このように, $5 \cdot 2$ 節で述べた絞りの要因の影響度は実 ラインにおいて確認されている.

これらの知見は, 日本鋼管(株)開発の NK-CAL プロ セスに全面的に取り入れられており，ストリップ形状を 良好な平坦度に保つための設備設計および操業上の指針 として有効に活用されている。

\section{7. 結}

言

ストリップのロール冷却時の熱応力による形状不良, 特に絞りに関して理論解析を行い, 絞りのメカニズム, 要因および対策を考察した。 その主な結果を次に示す.

( 1 ）ストリップ急冷時にはたとえ板幅方向に均一に冷 却されても, ライン方向温度勾配があるため, この部分 に熱応力が発生する.

( 2 )急冷開始部の板幅中央が最も座屈危険の大きな応 力状態になつて,この部位に座屈が起こる.

( 3 )この座屈波形が成長し, その形状のまま口ールを 通過できなくなると，折りたたまれた縦じわ形状の「絞 り」に至る.

(4) ストリップ寸法として板厚が大きく, 板幅の小さ いほど絞りにくい.

( 5 ) 絞りのその他の主要因はライン速度とロール冷却 
能力とライン張力である. ライン速度, ライン張力が大 きいほど, ロール冷却能力が小さいほど, 絞りは発生し にくい.

絞り発生危険部位の平均的な圧縮応力に対する絞り発 生限界応力の比として絞り指標 (Pinch Index =PI) を定 義した。このPIにより絞り発生危険の定量的な評価が 可能になり, 実ラインの操業上の絞り防止および新しい ラインの設備設計に役立つている.

\section{記 号}

$b:$ 矩形板の幅寸法 $(\mathrm{mm})$

$B I$ : 座屈指標 (Buckling Index)

$E:$ 板のヤング率 $\left(\mathrm{kgf} / \mathrm{mm}^{2}\right)$

$h:$ 板の座屈波形の高さ $(\mathrm{mm})$

$K_{A}:(12)$ 式の定数

$K_{B}:(5)$ 式の定数

$P I:$ 絞り指標 (Pinch Index)

$R:$ 水冷ロールの半径 $(\mathrm{m})$

$S:$ ストリップのライン方向温度勾配 $\left({ }^{\circ} \mathrm{C} / \mathrm{m}\right)$

$t:$ 板厚 $(\mathrm{mm})$

$V:$ ストリップ走行速度 $(\mathrm{m} / \mathrm{min})$

$W:$ 板幅 $(\mathrm{m})$

$\alpha$ : ロール冷却の総括熱貫流率 $\left(\mathrm{kcal} / \mathrm{m}^{2} \cdot \mathrm{h} \cdot{ }^{\circ} \mathrm{C}\right)$

$\phi: 2$ 軸応力場の臨界座屈応力の単軸応力場の臨界座屈
応力に対する比

$\sigma_{X M}$ : 座屈危険部位の板幅方向の最小熱応力 $\left(\mathrm{kgf} / \mathrm{mm}^{2}\right)$ $\sigma_{X}$ : 座屈危険部位の平均的な板幅方向圧縮応力 $\left(\mathrm{kgf} / \mathrm{mm}^{2}\right)$

$\sigma_{Y M}$ : 座屈危険部位のライン方向の最小熱応力 $\left(\mathrm{kgf} / \mathrm{mm}^{2}\right)$

$\sigma_{Y}$ : 座屈危険部位の平均的なライン方向応力 $\left(\mathrm{kgf} / \mathrm{mm}^{2}\right)$ $\sigma_{B}: 2$ 軸応力場における臨界座屈応力 $\left(\mathrm{kgf} / \mathrm{mm}^{2}\right)$

$\sigma_{C}$ : 一方向圧縮応力場における幅方向臨界座屈応力 $\left(\mathrm{kgf} / \mathrm{mm}^{2}\right)$

$\sigma_{e}:$ 板の降伏応力 $\left(\mathrm{kgf} / \mathrm{mm}^{2}\right)$

$\sigma_{P}:$ 絞り発生限界応力 $\left(\mathrm{kgf} / \mathrm{mm}^{2}\right)$

$\sigma_{T}$ : 外力負荷の板のライン方向応力 $\left(\mathrm{kgf} / \mathrm{mm}^{2}\right)$

$\nu:$ 板のポアソン比

\section{文献}

1 ) S. Fukuda, $N$. Yoshinara, $Y$. Ohkubo and $S$. Takushima: Trans. Iron Steel Inst. Jpn., 24 (1984), p. 734

2 ) 佐々木徹, 比良隆明, 阿部英夫, 柳島章也, 下山雄二, 田原紘一: 川崎製鉄技報, 16 (1984), p. 37

3 ) 的場 哲, 阿高松男, 青木 至, 辺見直樹: 鉄と鋼, 71 (1985), S 1183

4 ) 的場 哲, 阿高松男: 鉄と鋼, 72 (1986), S1250

5 ) 軽構造の理論とその応用 (上) 林毅編 (1966) [日本 科学技術連盟]

6 ) 益田森治, 室田忠雄: 工業塑性力学 (1967) [養賢堂] 